\title{
A Study on Infant Learning Thinking Based on the Integration of Truth and Reality
}

\author{
Yiran Zhang, Kailai Jiang \\ Zhejiang Normal University, Jinhua, China \\ Email: 810835511@qq.com
}

How to cite this paper: Zhang, Y.R. and Jiang, K.L. (2021) A Study on Infant Learning Thinking Based on the Integration of Truth and Reality. Open Access Library Journal, 8: e7437.

https://doi.org/10.4236/oalib.1107437

Received: April 21, 2021

Accepted: May 21, 2021

Published: May 24, 2021

Copyright $\odot 2021$ by author(s) and Open Access Library Inc.

This work is licensed under the Creative

Commons Attribution International

License (CC BY 4.0).

http://creativecommons.org/licenses/by/4.0/

(c) (i) Open Access

\begin{abstract}
This study focuses on the advertisement of children's mathematical thinking. It analyses the scientific nature of the advertisement (curriculum system) and summarizes some methods to cultivate logical thinking. It also points out the limit of the course, such as: children's action thinking has not been fully concerned, entity image thinking and mathematical language thinking is difficult to cultivate.
\end{abstract}

\section{Subject Areas}

Early Childhood Education

\section{Keywords}

Mathematical Logic Thinking, Children, Learning Thinking Course Advertising

\section{Introduction}

In life, it is not difficult to see some advertisements of early childhood education. In recent years, such advertisements have carried the banner of "AI Learning Thinking", trying to convince parents that children's learning mathematical thinking in early school age will have a great impact on their future life. However, what kind of thinking should children learn and whether the actual effect is as advertised? The text will theoretically explore the scientific nature and trap of this propaganda word.

\section{Advertising System of "3 - 8 Years Old Study Mathematics Thinking"}

On the market, a well-known M training institution has developed an AI learn- 
ing software, and sorted out the following five-order thinking training system (Table 1) for children's mathematical thinking training plate.

Carefully observing the curriculum system, it is not difficult to find that the cultivation of mathematical logical thinking has been consistent. From the age of 3 , children began to cultivate their logical ability from multiple perspectives including mathematics, graphics and space, audio-visual and multi-sensory. Moreover, a series of ability cultivation plans including practical ability, logical reasoning ability, spatial imagination ability, induction and arrangement ability, and application and transfer ability have been formulated.

\section{The Scientific Nature of Advertising and the Cultivation of Mathematical Logic Thinking}

\subsection{The Scientific Nature of the Course}

\subsubsection{Concerned about Children's Mathematical Logic Thinking}

According to the cognitive development theory of Vygotsky and Piaget, children are in the stage of external language. At this time, children's thinking is dominated by action, action appears before language, and the form of thinking is action, that is, action becomes the externalization of language. Children aged 2 to 7 were in the pre-operational stage of cognition. Therefore, preschoolers' thinking is mainly relatively specific representational thinking, but it is still limited by the

Table 1. The five-step thinking training system of a training institution.

\begin{tabular}{|c|c|c|}
\hline level & suitable age & Course content \\
\hline $\mathrm{S} 1$ & $\begin{array}{l}\text { Suitable for } 3 \text { - } 4 \text { year } \\
\text { old children to learn }\end{array}$ & $\begin{array}{l}\text { The concept of perceptual number, graphics, audio-visual } \\
\text { memory, logical analysis and other related knowledge, focus } \\
\text { on the development of children's observation and memory } \\
\text { ability, practical ability and logical reasoning ability. }\end{array}$ \\
\hline S2 & $\begin{array}{l}\text { Suitable for } 4 \text { - } 5 \text { year } \\
\text { old children to learn }\end{array}$ & $\begin{array}{l}\text { Learn the related knowledge of quantity, graphics, hands-on } \\
\text { puzzles and logical reasoning, and deeply cultivate children's } \\
\text { ability of observation and memory, hands-on practice and } \\
\text { logical reasoning. }\end{array}$ \\
\hline S3 & $\begin{array}{l}\text { Suitable for } 5 \text { - } 6 \text { year } \\
\text { old children to learn }\end{array}$ & $\begin{array}{l}\text { Learn numbers and operations, graphics and space, logic and } \\
\text { rules and other related knowledge, focusing on the } \\
\text { development of children's operational ability, spatial } \\
\text { imagination ability and logical reasoning ability. }\end{array}$ \\
\hline S4 & $\begin{array}{l}\text { Suitable for } 6 \text { - } 7 \text { year } \\
\text { old children to learn }\end{array}$ & $\begin{array}{l}\text { Learn numbers and operations, graphics and space, logic and } \\
\text { rules and other related knowledge, strengthen the cultivation } \\
\text { of children's ability to calculate, spatial imagination and the } \\
\text { ability to summarize and organize. }\end{array}$ \\
\hline S5 & $\begin{array}{l}\text { Suitable for } 8 \text { - } 9 \text { year } \\
\text { old children to learn }\end{array}$ & $\begin{array}{l}\text { Learn numbers and operations, logic and rules, time and } \\
\text { planning and other related knowledge, focusing on the } \\
\text { development of children's mathematical ability, spatial } \\
\text { imagination ability and application transfer ability. }\end{array}$ \\
\hline
\end{tabular}

Source: https://lx.huanqiu.com/article/7QYJNOodvZC/2019.10.22/2020.11.04 [1]. 
perspective of thinking, and it will show the thinking process dominated by action. Children's thinking in this period is a transitional period to logical thinking, and logical thinking is the main thinking that needs to be cultivated most. Therefore, according to the theory of educational psychology, it is not difficult to find that this curriculum system follows the law of children's cognitive development, focuses on the cultivation of logical thinking, respects the relatively specific imagery of children's thinking at this time, and combines graphics and spatial concepts in the curriculum.

\subsubsection{Pay Attention to Interesting and Logical}

The course combines mathematical thinking knowledge with AI interaction, provides professional teachers with synchronous guidance, adopts scientific and systematic teaching methods, and uses a variety of interesting teaching materials. The course content of each stage is combined with theory and practice, which helps children to build a complete thinking system while stimulating their interest in learning [2]. So as to help children get a head start in the future development of mathematical thinking.

\subsubsection{Pay Attention to the Study of Mathematical and Physical Foundation, with a Reasonable Level of Difficulty}

The difficulty rises spirally, from the simple to the deep, from the emphasis on feeling, experience and mathematics to the learning operation, which ensures the progress of the course and conforms to the cognitive development level of children. At the same time, each stage of learning tasks have different emphases; Throughout each focus, they from very specific learning to a less specific degree of learning, get rid of exam-oriented education of cramming primary school knowledge, follow the intellectual development of children. The core knowledge of mathematics learning runs through the course. The whole process of implicit number learning, from understanding the concept of number to learning how to operate, helps children build a scaffold leading to primary school mathematics.

\subsection{Children's Mathematical Logic Thinking and Cultivation}

Logical thinking includes formal logic, mathematical logic and dialectical logic [3]. Obviously, children's thinking has not formed dialectical logic at all, they only have shallow formal logic and mathematical logic, can simply compare and classify, can recognize symbols, and action dominates thinking.

To cultivate children's logical thinking, it is necessary to turn abstract logical thinking into operable concrete materials to help children lay mathematical foundation and logical thinking mode. This paper summarizes the following methods to cultivate logical thinking:

\subsubsection{Learn Mathematical Analysis and Comparison in Free Operation} Children's repeated manipulation and exploration in free operation can transform external actions into internal thinking changes, so that the problem-solving process is carried out in the mind, helping the formation of mathematical logic, 
simple mathematical analysis, and the development of children's mathematical logic thinking.

\subsubsection{Summarize Classification and Order Rules in Real Life}

Through observing life, children can learn some simple classification. For example, teachers can guide students to classify the vegetables and fruits they eat, so as to cultivate students' formal logic.

\subsubsection{Constructing the Ability of Relational Mathematical Reasoning and} Comprehensive Application in the Mobilization of Multiple Senses

Children's senses are very active, through the daily music environment, oral expression, visual color stimulation and physical behavior expression and so on to guide children's thinking to further mathematical logic. For example, mark the number on the seven colors of the rainbow, let children infer the order and size according to the color and number, analyze the relationship between the numbers from the overall view, and establish the ability of simple mathematical thinking.

\subsubsection{Cultivate Mathematical Logic Thinking through Art Forms}

Painting can show the thinking of children. In the process of painting, children express their ideas with the help of shapes and colors, and show them intuitively. At the same time, dance can also let children experience the logic of action thinking in action through physical movements.

\section{Limitations of the Course}

The presentation of advertisements seems very reasonable and scientific, but there are several pitfalls of "seduction" in the following aspects.

\subsection{Action, the Main Form of Children's Mathematical Logic Thinking, Has Not Received Complete Attention}

Although observational memory and hands-on ability are mentioned in the curriculum plan of the software, there are also corresponding teaching tools available for operation. However, its target audience is $3-8$ years old children, who may not be able to complete the operation of corresponding teaching AIDS according to the instructions. In addition, children also have the characteristics of intuitive action thinking to a large extent, so we must pay attention to the combination of action and children's specific image thinking in mathematical activities. Therefore, its operability to adapt to early children's action thinking is very small, and it fails to pay attention to the main thinking form of children, which is inevitably not suitable for the development of children.

\subsection{Physical Image Thinking Is Ignored}

The biggest drawback of software learning is that it is disembodied. In one study, cloth books were found to promote the development of small muscles by providing children with more hand manipulation. It is recognized in the academic 
world that entities can promote the all-round development of children's body and mind. The profundity of concrete image thinking is embodied in the continuous development of its thinking along intuitive action, concrete image and abstract logic. At the same time, but also cultivate the thinking of the broad, it is embodied in the children is through the multi-angle thinking to understand the characteristics of the rectangle. [4] Therefore, children's learning software is bound to affect the entity image thinking.

Although it has not been clearly pointed out whether there is an inevitable link between children's vision and the use of electronic products, some studies have shown that the high frequency use of electronic products will affect children's vision. In addition, many children have physiological hyperopia, which adversely affects the close use of electronic products.

\subsection{It Is Difficult to Cultivate Mathematical Language Thinking}

It can be seen from the above content that children are developing logical thinking, and the transition from lower-order thinking to higher-order thinking is particularly important. In the cultivation of logical thinking, the mathematical thinking brought by software is flat and unitary. It is difficult for children to exercise their language thinking in mathematical logic, while Vygotsky believes that the internalization of language brings about the improvement of thinking, and some scholars believe that a good thinking space of mathematical language should be constructed in mathematics teaching to strengthen the cultivation of students' mathematical language ability [5]. The lack of mathematical language cannot be ignored, and this is a major problem of the course.

\section{Conclusion}

This study focuses on the advertisement of children's mathematical thinking. According to the principle of educational psychology, the scientific nature of the advertisement of this course lies in the attention to children's mathematical logic thinking, interest and logic, and the study of mathematical and physical foundation. It also puts forward the strategies of cultivating mathematical logic thinking in operation, cultivating mathematical logic in real life, constructing logical thinking in a variety of senses, and cultivating logical thinking in art form. However, the irrationality of advertisement lies in three aspects: children's action thinking has not been fully concerned; entity image thinking and mathematical language thinking is difficult to cultivate.

\section{Conflicts of Interest}

The authors declare no conflicts of interest regarding the publication of this paper.

\section{References}

[1] Global Times (2019) How to Cultivate Children's Thinking Ability and Methods? Need to Build a Complete Thinking System [EB/OL]. (In Chinese) 
https://lx.huanqiu.com/article/7QYJNOodvZC/2019.10.22/2020.11.04

[2] Zhang, Y.M. and Li, X.Y. (2013) Children's Logic Based on the Analysis of Fairy Tales. Studies in Preschool Education, No. 4 (Serial No. 220), 12-17.

[3] Wang, X.C. (2010) Mathematical Thinking Method. People's Education Press, Beijing.

[4] Deng, Y. (1996) Several Strategies to Cultivate Children's Thinking Quality in Mathematics Activities. Studies in Preschool Education, No. 3 (Serial No. 57), 32-33. (In Chinese)

[5] Liu, H.W. and Zhang, W.Z. (2003) Instructional Gateways on Constructing Well MSI-thinking Space. Journal of Mathematics Education, 12, 28-30. (In Chinese) 